\author{
Barbara Baran \\ Zespół Szkół nr 1, Kraków
}

\title{
Problematyka rynku pracy w edukacji przedsiębiorczości
}

Transformacja systemu społeczno-gospodarczego prowadzi do zmian dotychczasowych zasad funkcjonowania poszczególnych dziedzin życia społecznego i gospodarczego. Proces ten wpłynął także na nową jakość rynku pracy oraz zmiany jego funkcjonowania. W konsekwencji przekształceniu uległy reguły gry na tym rynku, od niedoboru siły roboczej, który występował w gospodarce centralnie sterowanej, do pojawienia się coraz intensywniejszego nasilenia masowego bezrobocia. W tej nowej sytuacji należy uzmysławiać przyszłemu pracownikowi (uczniowi), że człowiek sam musi poszukiwać swojego miejsca na rynku pracy. Tylko aktywna postawa, wysokie kwalifikacje i poziom konkurencyjności jednostki przy poszukiwaniu pracy może doprowadzić do osiągnięcia przez nią sukcesu. Rozumiejąc zachodzące procesy i zasady funkcjonowania tego rynku łatwiej jest poszukiwać optymalnych rozwiązań w planowaniu i realizacji własnej kariery zawodowej.

Ze względu na wagę tematu w życiu społecznym i gospodarczym, wprowadzony nowy przedmiot $\mathrm{w}$ edukacji szkolnej podstawy przedsiębiorczości wiele miejsca poświęca zagadnieniom rynku pracy i zachowaniom się na nim.

W związku z tym, poniżej będę zmierzać do przedstawienia problematyki funkcjonowania rynku pracy oraz struktury zatrudnienia, w które powinien być wyposażony uczeń na lekcjach $\mathrm{z}$ tego przedmiotu. Treści te powinny wpłynąć na mobilizowanie go do nauki i rozwoju osobowości oraz kształtowanie postaw konkurencyjnych. Wydaje się, że mogą być wykorzystane także $\mathrm{w}$ procesie tworzenia warsztatu nauczyciela przedsiębiorczości.

Poniżej ograniczę się do przedstawienia mechanizmu kształtowania rynku pracy, zmiany form aktywności zawodowej, wpływu polityki zatrudnienia państwa na rynek pracy oraz wpływu postępu technicznego na ten rynek. Rozważania te zilustrowane będą analizą zmian struktury zatrudnienia w Polsce w podstawowych sektorach gospodarki, w przedsiębiorstwach o różnych formach własności oraz zmian współczynnika aktywności zawodowej i współczynnika zatrudnienia w latach 1994-2003.

W literaturze przedmiotu wiele miejsca poświęca się problematyce rynku pracy (por. prace: Gogolewska 1999, Guzik 1999, Dach 1994, Grzywacz 2002, Padowicz 2002). W pracach tych główną uwagę zwrócono na politykę zatrudnienia państwa, funkcjonowanie rynku pracy, metody oddziaływania państwa na aktywizowanie zasobów pracy. ${ }^{1}$

Rynek pracy jest jednym z ogniw procesu gospodarowania zasobami ludzkimi. Praca ludzka jest regulowana prawami popytu i podaży. Rynek pracy jest więc obszarem wzajemnego oddziaływania elementów tego rynku.

W literaturze przedmiotu rynek pracy traktowany jest jako „stan, w którym mają miejsce ekonomiczne transakcje: $\mathrm{z}$ jednej strony najmowanie (angażowanie) ludzi do pracy,

\footnotetext{
${ }^{1}$ Szczególnie wiele miejsca problematyce rynku pracy poświęcają liczne czasopisma naukowe: Polityka społeczna, Życie gospodarcze, Nowe Życie Gospodarcze, Gospodarka Narodowa, Praca i zabezpieczenie społeczne oraz Rzeczpospolita i Gazeta Wyborcza. Najnowsze dane statystyczne dostępne są na stronie internetowej GUS (www.stat.gov.pl)
} 
z drugiej zaś - sprzedaż swojej pracy. "(Dach 1994, s. 65). Na rynku pracy dokonuje się rozmieszczenia ludności według dostępnych miejsc pracy, poprzez który zagospodarowuje się zasoby siły roboczej i koordynuje decyzje o jej zatrudnieniu. (Guzik, 1999, s. 221)

Elementami rynku pracy są:

- popyt na siłę roboczą,

- podaż siły roboczej,

- płaca, która jest wyrazem równowagi zachodzących stosunków między pracodawcami i pracobiorcami

Podmiotami tego rynku są pracodawcy (przedsiębiorstwa, instytucje, osoby fizyczne) oferujący wolne miejsca pracy i pracobiorcy, czyli osoby pojawiające się na tym rynku $\mathrm{w}$ celu zawarcia stosunku pracy.

„Popyt na pracę to ilościowe zapotrzebowanie na pracę ludzką, co wyrażamy liczbą miejsc pracy i czasu pracy na tych stanowiskach, które pracodawcy oferują pracobiorcom." (Guzik 1999, s. 223), zaś „podaż siły roboczej wyrażamy liczbą osób zatrudnionych oraz poszukujących pracy lub zasobem czasu pracy wykorzystywanego i możliwego do wykorzystania w gospodarce." (Guzik 1999, s. 223)

Ryc. 1. Rynek pracy w ujęciu klasycznym

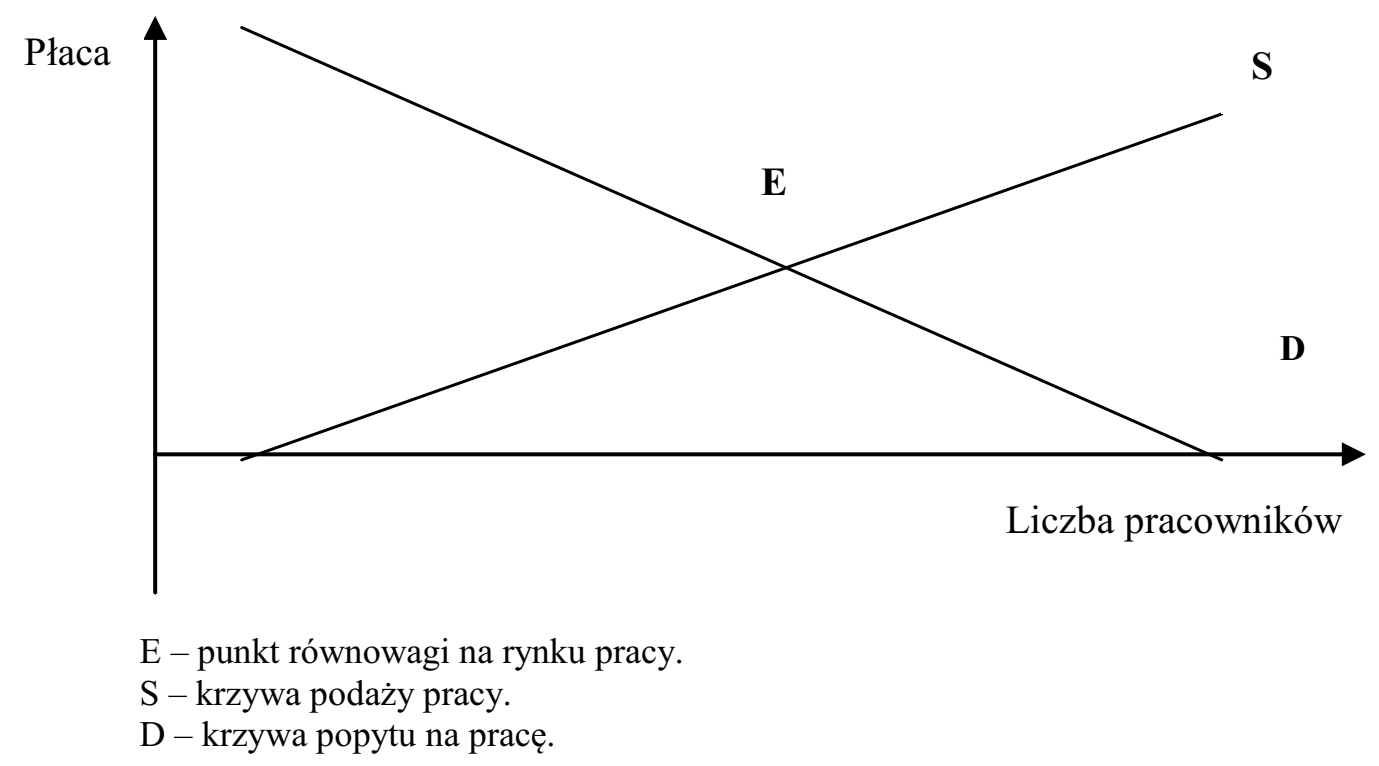

Źródło : Za J. Gogolewską,1999. s. 477.

Jak przedstawiono na ryc. 1 rynek pracy osiąga równowagę (pkt. E), jeżeli podaż pracy $(\mathrm{S})$ jest równa popytowi na pracę $(\mathrm{D})$, przy pewnym poziomie płac $\left(\mathrm{P}_{\mathrm{o}}\right)$. Okazuje się wówczas, że liczba miejsc pracy odpowiada liczbie chętnych do pracy. W praktyce rozwiązanie takie może ulec zniekształceniom i grozi powstaniem tzw. ukrytego bezrobocia.

W literaturze występuje również pojęcie racjonalnego zatrudnienia, gdzie występuje niewielka stopa bezrobocia (4,5 -5\%). Bezrobotnymi pozostają ludzie, którzy z własnej woli, przy określonej płacy nie decydują się podjąć pracy.

J. Gogolewska (1999) twierdzi, że powinno się dążyć do takiego stanu, ponieważ wpływa to na zadowolenie ludzi z pracy, wzrost ich kwalifikacji, osłabia występowanie negatywnych zjawisk, jak np. absencja, fluktuacja kadr. Ponadto wpływa na poprawę wydajności pracy, wzrost płac, rozwój gospodarczy. Racjonalne zatrudnienie przyczynia się do optymalnego wykorzystania potencjału zasobów pracy. 
W rzeczywistości możemy mieć do czynienia z niedoborem zasobów pracy lub ich nadmiarem. Gdy na rynku wystąpi brak ludzi do pracy (niedobór), wówczas wśród pracodawców uruchamia się mechanizm konkurencyjności, w wyniku którego oferują oni coraz lepsze warunki pracy, m.in. wzrost wynagrodzenia za pracę. $\mathrm{W}$ warunkach niedoboru miejsc pracy, dochodzi do konkurencji między pracobiorcami, którzy są gotowi pracować w gorszych warunkach, za niższe wynagrodzenie. Prowadzi to często do nadmiernego wzrostu bezrobocia, które jest szkodliwe społecznie. Reguły rynkowe w tej sytuacji nie rozwiązują problemu bezrobocia. Wyłania się więc potrzeba, aby na polu polityki społecznej, państwo dążyło do ograniczenia tego negatywnego zjawiska.

Rynek pracy funkcjonuje w określonym otoczeniu, które tworzy polityka zatrudnienia, gospodarka narodowa, ulegająca ciągłym zmianom, oraz instytucje finansowe.

Reguły rynkowe, które wykorzystuje gospodarka, zmierzają do ograniczenia wpływu państwa na rynek pracy. Państwo pełni rolę podmiotu tworzącego prawo, warunkujące realizację funkcji rynku pracy. Regulacje prawne określają prawa i obowiązki poszczególnych uczestników rynku pracy.

H. Guzik (1999) stwierdza, że kształtowanie popytu na pracę zależy od koniunktury gospodarczej, treści przemian profilów produkcyjno-usługowych, wielkości i struktury naturalnych ubytków zasobów pracy, dynamiki wydajności pracy, stopnia dyspozycyjności zatrudnionych, opłacalności substytucji pracy żywej przez uprzedmiotowioną, poziomu mechanizacji, automatyzacji, komputeryzacji.

Natomiast płaca jest jednym z najważniejszych czynników wpływających na popyt.

Przez pracę uprzedmiotowioną rozumie się ,pracę minioną znajdującą wyraz w środkach produkcji i materialnych przedmiotach czy artykułach konsumpcyjnych. Środki rzeczowe, kapitałowe zastępują nakłady pracy żywej”. (Dowgiałło, 1993, s. 150)

Wzrost gospodarczy wpływa pobudzająco na dopływ kapitału inwestycyjnego, co z reguły przyczynia się do zwiększenia zapotrzebowania na siłę roboczą. Natomiast obniżanie kosztów produkcji, na przykład poprzez wzrost wydajności pracy oraz ograniczenie kosztów pracy, prowadzi do zmniejszenia popytu na pracę.

Koszty pracy obejmują sumę wynagrodzeń wypłacanych zatrudnionym za rzeczywiście wykonaną pracę i kosztów (korzyści) nie związanych bezpośrednio z wykonywaną pracą, poniesionych przez pracodawcę na rzecz pracobiorcy $\mathrm{w}$ formie pieniężnej i niepieniężnej. (Penc, 1997, s. 209)

Wysoki stopień automatyzacji i komputeryzacji procesów produkcyjnych zmniejsza oferowaną na ryku pracy liczbę miejsc pracy. Zwiększa natomiast wymagania co do pozio$\mathrm{mu}$ wykształcenia potencjalnych pracowników. Stwarza to potrzebę zatrudniania ludzi o wysokich kwalifikacjach.

Na wielkość popytu na pracę mają też wpływ wzajemne stosunki między związkami zawodowymi, związkami pracodawców oraz państwem. Zbyt silne związki zawodowe walczące o wysoki poziom socjalno - bytowy pracowników zatrudnionych, mogą przyczyniać się do powstania wysokich kosztów pracy. Zmniejszy to wtedy dążenie pracodawcy do tworzenia nowych miejsc pracy oraz obniżanie konkurencyjności produktów. Jednak układy pomiędzy związkami a pracodawcami muszą być zgodne z ustawami państwa, które odnoszą się do czasu pracy, warunków pracy, minimalnego wynagrodzenia, itp.

Podaż zasobów pracy zależy od wielu czynników. Są to według H. Guzik (1999, s. 223) czynniki: demograficzne, prawne, socjoekonomiczne.

Potencjał pracy jest głównym czynnikiem kształtującym podaż pracy. Jego wielkość zależy od liczby ludzi czynnych zawodowo oraz od wymiaru czasu pracy osób zatrudnionych. Ma na to wpływ przyrost demograficzny, migracje ludności wewnętrzne i zagraniczne (zwłaszcza emigracja).

Rynek pracy jest zróżnicowany przestrzennie. W zależności od obszaru można wyróżnić: rynek lokalny, regionalny, międzyregionalny, europejski, światowy. Rynek pracy jest dynamiczny, ulega ciągłym zmianom w wyniku przemieszczania się zasobów pracy (ludno- 
ści $\mathrm{w}$ wieku produkcyjnym) $\mathrm{w}$ poszukiwaniu pracy. Na zasoby pracy wpływają również zmiany w poziomie aktywności zawodowej ludności w wieku przed i poprodukcyjnym.

Skracanie wymiaru czasu pracy zatrudnionych zwiększa potencjał pracy na rynku i stwarza nowe możliwości zatrudnienia. Wymiar czasu pracy zależy od: skracania czasu pracy, pracy $\mathrm{w}$ godzinach nadliczbowych, absencji w pracy, przestojów oraz strat czasu pracy.

Poziom intensywności pracy ma znaczący wpływ na rozmiary zasobów pracy. Jeśli określony przydział pracy zostanie szybciej wykonany, to w efekcie dla uzyskania tej samej produkcji potrzebnych jest mniej rąk do pracy. Jednak jest to proces bardziej złożony, bowiem można rozwijać skalę produkcji, oferując wtedy nowe miejsca pracy.

Podaż pracy zależy także od preferencji czy tradycji społecznych, cen towarów i usług. Jakość podaży siły roboczej zależy od poziomu wykształcenia społeczeństwa oraz od ich stanu zdrowia. Lepiej wykształcony pracownik oferuje wyższe umiejętności, co równocześnie zwiększa jego wydajność. (Guzik, 1999)

Zasoby siły roboczej (podaży pracy) charakteryzują się ciągłymi zmianami związanymi z przepływem ludności w różne formy aktywności zawodowej.

W analizie rynku pracy podstawowe znaczenie mają pojęcia odnoszące się do różnych kategorii osób funkcjonujących na rynku pracy (Rocznik Statystyczny 2003, s. 133) :

1) Do zatrudnionych zalicza się osoby, które pracują na podstawie zawartego stosunku pracy, tj. umowy o pracę, powołania lub wyboru.

2) Do pracujących zalicza się osoby, które w badanym tygodniu:

a) wykonywały pracę przynoszącą zarobek lub dochód albo pomagały (bez wynagrodzenia) w prowadzeniu rodzinnego gospodarstwa rolnego lub rodzinnej działalności gospodarczej,

b) nie wykonywały pracy (np. z powodu choroby, urlopu, przerwy w działalności zakładu), ale formalnie miały pracę.

3) Do bezrobotnych zalicza się osoby wieku 15-74 lat, które spełniły jednocześnie następujące warunki:

a) W okresie badanego tygodnia nie były osobami pracującymi,

b) w ciągu 4 tygodni aktywnie poszukiwały pracy,

c) były gotowe podjąć pracę;

d) zaliczono także osoby, które znalazły pracę i oczekiwały na jej rozpoczęcie (w okresie 3 miesięcy).

4) Do biernych zawodowo zalicza się osoby, których nie zakwalifikowano do pracujących lub bezrobotnych.

W świetle zachodzących zmian na rynku pracy (w kategoriach zatrudnienia) można przyjąć, że część osób pracujących może zmieniać miejsce pracy (ryc. 2) lub zostać jej pozbawionym. Zmniejszy się wówczas liczba pracujących, a zwiększy grono bezrobotnych. Liczba bezrobotnych może się zmniejszyć w wypadku znalezienia przez nich nowych miejsc pracy. Pewna grupa bezrobotnych może zrezygnować z poszukiwania pracy, zwiększając grono osób biernych zawodowo. Niektóre osoby bierne zawodowo mogą zdecydować o zamiarze podjęcia pracy, powiększając grono osób poszukujących pracy lub podjąć zatrudnienie. Grupa osób biernych zawodowo powiększa się również o ludzi, którzy przeszli na emeryturę, rentę lub zrezygnowali z pracy np. w celu wychowywania dzieci lub podnoszenia kwalifikacji. 
Ryc. 2. Przepływ między różnymi kategoriami ludności na rynku pracy.

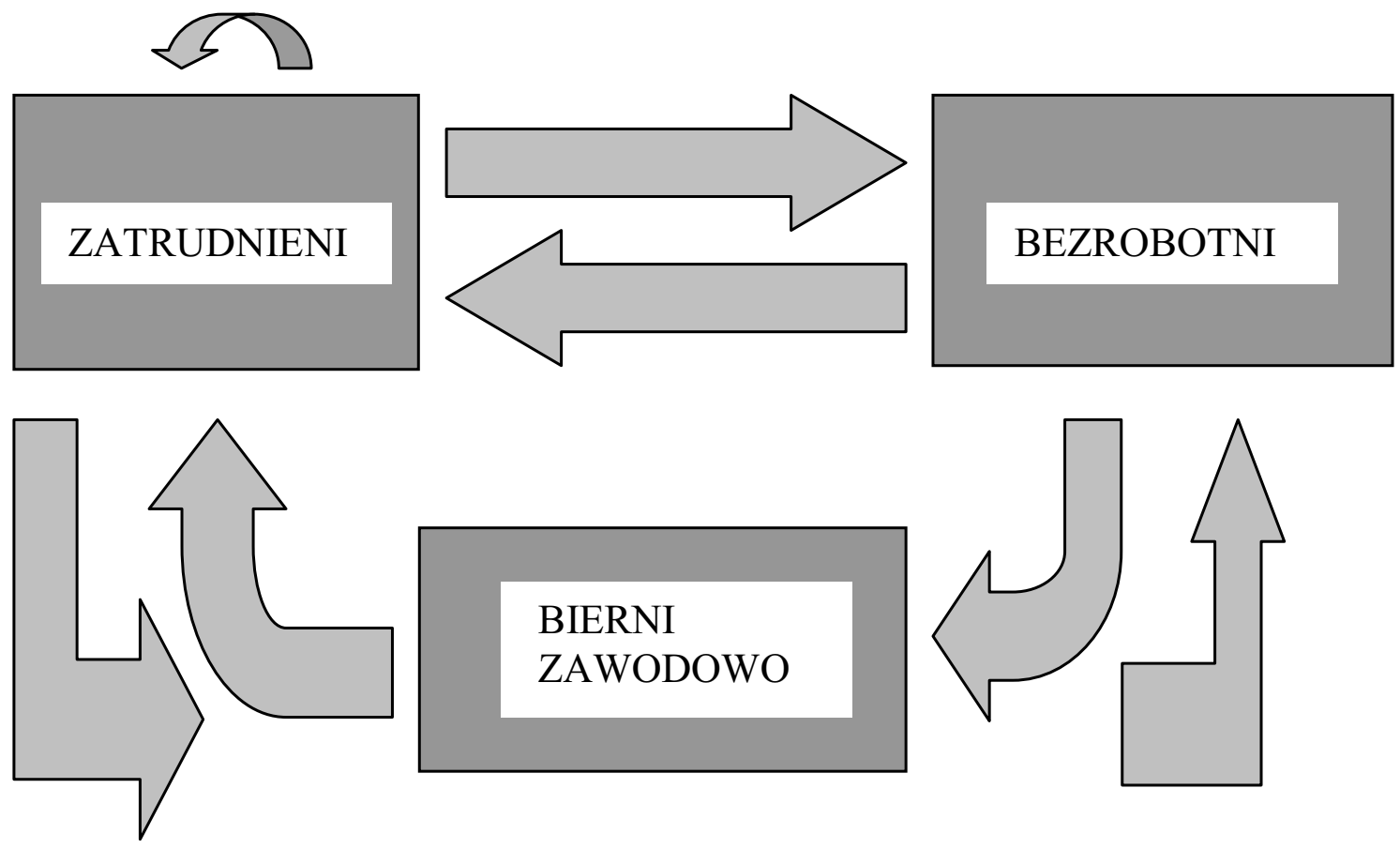

Źródło : J. Gogolewska,1999, s. 468.

Polityka społeczna państwa pełni rolę stymulującą na rynku pracy. Są to głównie działania w zakresie polityki zatrudnienia, do których należy (Guzik 1999):

- wywieranie wpływu na wzrost popytu na siłę roboczą,

- oddziaływania zmniejszające siłę roboczą,

- zawieranie międzynarodowych porozumień w sprawie transferu siły roboczej.

J. Gogolewska (1999) uważa, że zwiększanie liczby miejsc pracy można osiągnąć przez aktywną politykę zatrudnienia w drodze :

a) subwencjonowania płac i zatrudnienia,

b) tworzenia w sektorze państwowym specjalnych programów zatrudnienia,

c) popierania przedsiębiorczości, stymulowanie rozwoju małych i średnich przedsiębiorstw, wspomaganie lokalnych inicjatyw wzrostu zatrudnienia, pomoc w rozwijaniu działalności gospodarczej przez bezrobotnych lub zagrożonych bezrobociem,

d) robót publicznych.

Subwencjonowanie płac i zatrudnienia ma na celu nakłonienie pracodawców do tworzenia nowych miejsc pracy, bądź rezygnacji z redukcji zatrudnienia. Może przyjąć to charakter pokrywania przez państwo całości lub części płac nowo zatrudnionych $\mathrm{w}$ postaci ulgi podatkowej proporcjonalnej do liczby zatrudnionych. Zatrudnienie wówczas wzrasta, bo siła robocza dla pracodawcy jest tańsza. Jednak jest to rozwiązanie drogie dla państwa i przyczynia się do powstawania korupcji.

Specjalne programy zatrudnienia w sektorze państwowym powstają dla aktywizacji zawodowej w regionach o dużym wskaźniku bezrobocia. Dają one możliwość zatrudnienia osób długo pozostających bez pracy.

Ważnym elementem aktywnej polityki zatrudnienia jest także wspieranie indywidualnej przedsiębiorczości. Są to specjalne programy państwa dla stworzenia sprzyjających warunków głównie dla rozwoju małych i średnich firm np.: kredyty udzielane przez specjalnie 
powołane instytucje finansowe, przyznawanie ulg podat-kowych, tworzenie tzw. inkubatorów przedsiębiorczości, itp.

Inną formą pomocy państwa na rzecz ograniczenia bezrobocia jest wspieranie samozatrudniania, zwłaszcza przez bezrobotnych. Państwo ułatwia im uzyskanie preferencyjnych kredytów na założenie i rozwinięcie własnej działalności gospodarczej.

Kolejną możliwością ograniczenia bezrobocia jest tworzenie wolnych stref gospodarczych, na terenie których powstają $\mathrm{w}$ miarę dogodne warunki dla przyciągania inwestycji i powstawania nowych miejsc pracy.

Aktywizację zasobów pracy zwłaszcza w układach samorządowych można realizować poprzez roboty publiczne, mające na celu poprawienie jakości infrastruktury. Są to prace m.in. przy budowie dróg, lotnisk, kanałów, regulacji rzek oraz melioracji. Tworzone nowe miejsca pracy okresowo eliminują bezczynność bezrobotnych oraz skracają czas oczekiwania na stałą pracę. Do robót tych zwykle zatrudniane są osoby długo pozostające bez pracy, bowiem w tym okresie obniża się ich przydatność zawodowa. Działania te podejmowane są ze względów społecznych.

W ramach polityki zatrudnienia kształtuje się podaż siły roboczej przez dostarczanie systemowi oświaty informacji na temat zachodzących zmian na rynku pracy. Zachodzi bowiem konieczność dostosowania do tego rynku kierunków szkolenia zawodowego.

Państwo może również podejmować działania ograniczające podaż siły roboczej przez zmniejszanie jej zasobów. Osiąga to przez tworzenie aktów prawnych oddziałujących na rynek pracy. Dotyczą one m. in.:

- umożliwienia wcześniejszego przechodzenia na emeryturę,- przedłużania okresu kształcenia,

- przedłużania lub wprowadzenia obowiązkowej służby wojskowej,- zachęty dla kobiet, aby wydłużały okres opieki nad dziećmi (Gogolewska 1999).

Ingerencja państwa w wymiar godzin zatrudnienia w celu ograniczenie bezrobocia przyjmuje formy: skracania czasu pracy, wydłużania urlopów, zmniejszenia dopuszczalnej liczby godzin nadliczbowych, zatrudniania w niepełnym wymiarze czasu pracy (Guzik 1999).

Działania powyższe nie są jednak najlepszym rozwiązaniem społecznym, ani ekonomicznym. W praktyce najczęściej $\mathrm{z}$ powyższych form stosuje się zatrudnianie $\mathrm{w}$ niepełnym wymiarze czasu. Jest to związane $\mathrm{z}$ niewielkimi kosztami aktywizacji zawodowej.

Inną formą wpływu polityki zatrudnienia na rynek pracy jest przyznawanie zasiłków dla bezrobotnych, zasiłków z funduszu pomocy socjalnej, przyznawanie odszkodowania dla osób zwalnianych. Ma to chronić bezrobotnego przed drastycznym pogorszeniem warunków jego życia.

Rynek pracy nie zamyka się w obrębie jednego państwa. Przyjmuje zasięg europejski (rynek pracy państw Unii Europejskiej, czy rynek Wschodniej Europy), a także światowy (państw rozwiniętych Ameryki Północnej, Japonii oraz państw Ameryki Południowej, Afryki i Azji). Ludność emigruje w poszukiwaniu pracy czasowej lub stałej. W tej sytuacji walka $\mathrm{z}$ bezrobociem powinna być skoordynowana w skali międzynarodowej. Integracja gospodarek państw, jak w Unii Europejskiej, powinna zapobiegać dyskryminacji i nieuczciwej konkurencji oraz wpływać na wzrost mobilności i podnoszenia kwalifikacji siły roboczej.

Globalizacja i rozwój nowoczesnej techniki wpływa na rynek pracy. Powstaje popyt i podaż pracy o zasięgu międzynarodowym. W dobie technologii informatycznej zatrudnienie znajdą pracownicy o wysokich kwalifikacjach, a globalizacja umożliwia im swobodne przemieszczanie się na rynku pracy. T. Zalega (2002) uważa, że rozwój technologii informacyjnej „modyfikuje tradycyjne sposoby życia i pracy, umożliwiając nie tylko przekazywanie danych, tekstów czy obrazów z przedsiębiorstwa do przedsiębiorstwa lub z centrali do filii, ale również do stanowisk pracy, usytuowanych na całym świecie". Taki system współpracy pracownika z pracodawcą czy z kontrahentami wprowadza zasadę pracy zdalnej, telepracy, czy pracy sieciowej, itp. Pracownik powinien posiadać cechy osobowościowe takie jak: 
samodzielność, gotowość do zmian i ciągłej nauki oraz posiadać szeroką wiedzę i umiejętności.

Przedstawiony powyżej system pracy umożliwia większą elastyczność zatrudnienia i płac. Elastyczność rynku pracy jest rozumiana ,jako zdolność łatwego przystosowania się do zmieniających się warunków"(Kryńska, 2001, s. 74). W literaturze przedmiotu elastyczność rynku pracy jest przedstawiana jako elastyczność zatrudnienia, elastyczność czasu pracy oraz elastyczność płac. Elastyczność zatrudnienia oznacza zdolność dostosowania liczby zatrudnionych w przedsiębiorstwie i czasu ich pracy do zmieniających się warunków, np. koniunktury, rentowności, wydajności pracy. Elastyczność czasu pracy oznacza możliwość dostosowania długości czasu pracy i jego organizacji do potrzeb przedsiębiorstwa, grup pracowników lub wykonywanego zadania. Elastyczność płac obejmuje proces dostosowywania wysokości i struktury wynagrodzeń do zmian wydajności pracy, rentowności działalności i sytuacji panującej na rynku pracy. (Kryńska, 2001, s. 74)

$\mathrm{W}$ praktyce podejmowane są między innymi następujące działania $\mathrm{w}$ ramach uelastycznienia rynku pracy:

- w miejsce długoterminowych umów o pracę wprowadzane są prace chałupnicze, prace w niepełnym wymiarze czasu, wykonanie określonego zadania;

- $\quad$ wprowadzanie umowy o pracę na czas określony;

- $\quad$ wprowadzanie pracy dorywczej (tymczasowej);

- zatrudnianie do realizacji określonych programów;

- samozatrudnianie osób wykonujących usługi dla przedsiębiorstwa w zakresie np. prac porządkowych, remontowych, czy doradczych, projektowych;

- wypożyczanie pracowników do realizacji określonych zadań lub na zastępstwo;

- zmienny czas pracy dostosowany do potrzeb działalności firmy w ramach ustawowego czasu pracy;

- $\quad$ wprowadzanie pracy na telefon, czyli pracownik pozostaje do dyspozycji pracodawcy a podejmuje ją na wezwanie.

Elastyczność zatrudnienia wpływa na obniżenie kosztów pracy, tworzenie większej liczby miejsc pracy, racjonalne wykorzystanie zasobów pracy na rynku pracy, wzrost konkurencyjności zakładu, ale zarazem wprowadza ograniczenie praw pracowniczych, brak stabilizacji zawodowej i życiowej, stwarza gorsze warunki płacy oraz brak identyfikowania się z rozwojem przedsiębiorstwa. Jest to często związek o charakterze zadaniowym. (Zalega 2002, s. 27)

Transformacja gospodarcza w Polsce spowodowała zmiany w strukturze rynku pracy. Nastąpił spadek udziału pracujących w sektorze przemysłowo - budowlanym, bowiem zgodnie z Małym rocznikiem statystycznym Polski (2002) w 1995 sektor ten zatrudniał 4569,8 tys. pracujących (tj. 30,2\%), a w 2001 roku - 3780,1 tys. pracujących (tj. 25,3\%). Jednocześnie nastąpił wzrost udziału pracujących w sektorze usług. W 1995 roku w usługach pracowało 6365,8 tys. pracujących (tj. 42,5\%), a w 2001 roku - 6879,1 tys. pracujących (tj. $46,0 \%$ ). Jest to tendencja zgodna $\mathrm{z}$ kierunkiem zmian, jakie zaszły $\mathrm{w}$ państwach wysoko rozwiniętych. Natomiast w sektorze rolnictwa, pozostaje jeszcze duża liczba pracujących, co jest niekorzystne dla gospodarki. W. Padowicz (2002) uważa, że trójsektorowy podział struktury pracujących w Polsce jeszcze znacznie odbiega od struktur istniejących w Unii Europejskiej (w końcu lat dziewięćdziesiątych średnie wskaźniki udziału trzech sektorów wynosiły: sektor rolniczy 5\%, sektor przemysłowy $30 \%$, sektor usługowy $65 \%$ ).

Strukturę pracujących według sekcji na koniec 2001 roku przedstawia tabela 1.

W latach transformacji nastąpiły zmiany wartości współczynnika aktywności zawodowej społeczeństwa w Polsce oraz wartości wskaźnika zatrudnienia. Przez współczynnik aktywności zawodowej rozumie się „udział osób aktywnych zawodowo w liczbie ludności (w wieku 15 lat i więcej) ogółem oraz danej grupy”. Wskaźnik zatrudnienia to „udział pracu- 
jących w liczbie ludności (w wieku 15 lat i więcej) ogółem oraz danej grupy”. (Rocznik Statystyczny 2003, s. 134).

Tab. 1. Pracujący według sekcji w Polsce (stan w dniu 31 grudnia 2001).

\begin{tabular}{|c|c|c|}
\hline Sekcje w gospodarce & $\begin{array}{c}\text { Pracujący } \\
\text { w tys. }\end{array}$ & $\begin{array}{c}\text { Struktura } \\
\text { pracujących }\end{array}$ \\
\hline Ogółem : & 14963,1 & 100,0 \\
\hline Rolnictwo, łowiectwo i leśnictwo: & 4296,0 & 28,7 \\
\hline Rybołówstwo i rybactwo: & 7,9 & 0,1 \\
\hline Przemysł: & 3008,1 & 20,1 \\
\hline Budownictwo: & 772,0 & 5,2 \\
\hline Handel i naprawy: & 2096,2 & 14,0 \\
\hline Hotele i restauracje: & 231,5 & 1,5 \\
\hline Transport i łączność: & 733,9 & 4,9 \\
\hline Pośrednictwo finansowe: & 285,9 & 1,9 \\
\hline Obsługa nieruchomości i firm, nauka: & 841,3 & 5,6 \\
\hline Administracja publ., obrona narodowa, ob. ubezp. społeczne: & 526,6 & 3,5 \\
\hline Edukacja: & 915,6 & 6,1 \\
\hline Ochrona zdrowia i opieka społeczna: & 865,0 & 5,8 \\
\hline Pozostała działalność usługowa: & 383,1 & 2,6 \\
\hline
\end{tabular}

Źródło: Mały rocznik statystyczny Polski GUS 2002, s. 140

Zmiany współczynnika aktywności zawodowej i wskaźnika zatrudnienia w latach $1994-2003$ przedstawia ryc. 3 i tab. 2.

Ryc. 3. Zmiany współczynnika aktywności zawodowej i wskaźnika zatrudnienia w latach $1994-2003$.

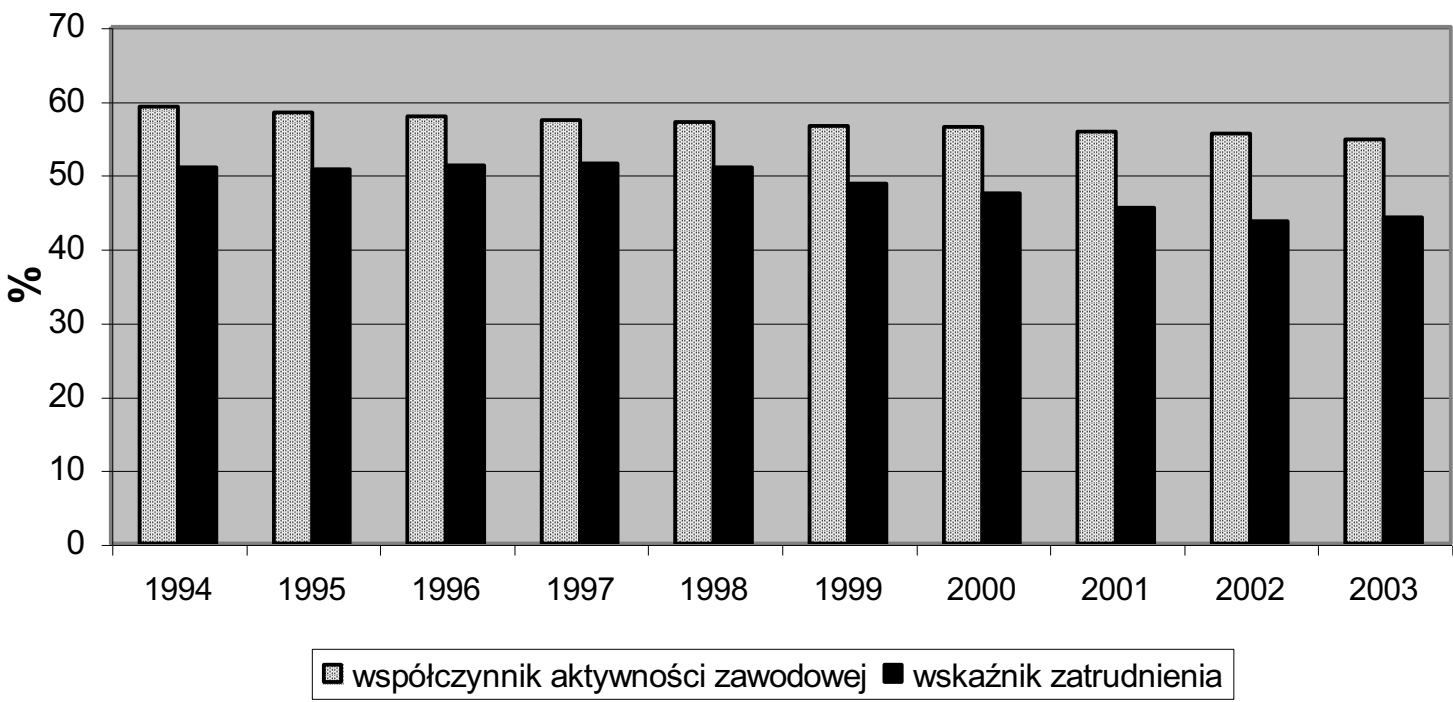

Źródło: Rocznik statystyczny GUS za lata 1994-2003, Mały rocznik statystyczny Polski,2004

W IV kw. 1995 roku aktywność zawodowa ludności w wieku 15 lat i więcej wynosiła 17004 tys. (w tym: pracujących 14771 tys., bezrobotnych 2233 tys.), współczynnik aktywności zawodowej wynosił 58,4\%, a wskaźnik zatrudnienia wynosił 50,7\%. Można zauważyć stopniowe obniżanie się popytu na pracę od 1998 roku, kiedy współczynnik aktywności 
zawodowej wynosił 57,1\%, a wskaźnik zatrudnienia 51,0\%. Natomiast w IV kw. 2003 roku aktywność zawodowa wymienionej wcześniej populacji wynosiła 16991 tys. (w tym: pracujących 13718 tys., bezrobotnych 3273 tys.), współczynnik aktywności zawodowej wyniósł 54,8\%, a wskaźnik zatrudnienia 44,2\%. (Mały rocznik statystyczny Polski 2002, s. 136 oraz 2004)

Tab. 2. Aktywność ekonomiczna ludności w wieku 15 lat i więcej w latach 1994-2003.

\begin{tabular}{|l|l|l|l|l|l|l|l|l|l|l|l|}
\hline Lata & 1994 & 1995 & 1996 & 1997 & 1998 & 1999 & 2000 & 2001 & 2002 & 2003 \\
\hline $\begin{array}{l}\text { Współcz. } \\
\text { aktywności } \\
\text { zawodowej }\end{array}$ & 0 & 59,2 & 58,4 & 57,9 & 57,4 & 57,1 & 56,6 & 56,4 & 55,8 & 55,0 & 54,8 \\
\hline $\begin{array}{l}\text { Wskaźnik } \\
\text { zatrudnienia }\end{array}$ & o 51,0 & 50,7 & 51,2 & 51,5 & 51,0 & 48,0 & 47,4 & 45,5 & 44,1 & 44,2 \\
\hline
\end{tabular}

Źródło: Rocznik Statystyczny GUS za lata 1995-2003, Mały rocznik statystyczny Polski,2004

Analizując rynek pracy w Polsce należy dokonać przeglądu aktywności zawodowej ludności na tle międzynarodowym (tab. 3).

Tab. 3. Ludność aktywna zawodowo w wieku 15 lat i więcej w 2000 roku *.

\begin{tabular}{|l|c|c|}
\hline \multicolumn{1}{|c|}{ Kraje } & $\begin{array}{c}\text { Ludność aktywna zawodowo } \\
\text { w \% ogółu ludności }\end{array}$ & $\begin{array}{c}\text { Współczynnik aktywności } \\
\text { zawodowej\% }\end{array}$ \\
\hline Austria & 48,3 & 58,1 \\
\hline Belgia & 43,0 & 52,2 \\
\hline Dania & 53,7 & 65,5 \\
\hline Finlandia & 50,4 & 61,6 \\
\hline Francja & 45,1 & 55,7 \\
\hline Grecja & 43,0 & 50,0 \\
\hline Hiszpania & 43,0 & 50,5 \\
\hline Irlandia & 46,0 & 58,8 \\
\hline Niderlandy & 51,6 & 63,5 \\
\hline Niemcy & 48,4 & 57,1 \\
\hline Norwegia & 52,3 & 65,6 \\
\hline Polska $* *$ & 44,8 & 56,4 \\
\hline Portugalia & 51,2 & 61,7 \\
\hline Republika Czeska & 50,5 & 60,4 \\
\hline Rosja $* * *$ & 47,7 & 58.8 \\
\hline Szwajcaria & 55,6 & 67,4 \\
\hline Szwecja & 49,2 & 60,4 \\
\hline Turcja*** & 36,9 & 51,8 \\
\hline Ukraina & 47,0 & 56,9 \\
\hline Węgry & 41,0 & 53,5 \\
\hline W. Brytania & 50,3 & 62,3 \\
\hline Włochy & 41,2 & 48,1 \\
\hline
\end{tabular}

* Dane na podstawie badań aktywności ekonomicznej ludności : w Turcji - 12 lat i więcej, w Hiszpanii i W. Brytanii- 16 lat i więcej, w Danii - 15 - 66 lat, w Rosji - 15 - 72 lata, w Finlandii i na Węgrzech- 15 - 74 lata, w Szwecji- 16 - 64 lata, w Norwegii- 16 - 74 lata.

** Dane dotyczą IV kwartału

*** 1999 rok

Źródło: Mały rocznik statystyczny Polski, GUS,2002, s. 515

Niniejszym należy podkreślić, iż aktywność zawodowa ludności w 2000 roku w różnych krajach europejskich waha się od $41,0 \%$ do $55,6 \%$, przy $44,8 \%$ w Polsce. Wynika to w 
znacznym stopniu z zaawansowania procesu starzenia ludności oraz ustaleń prawnych związanych z wiekiem emerytalnym. Największymi wskaźnikami charakteryzują się Szwajcaria $55,6 \%$, Dania 53,7\%, Norwegia 52,3\%, Niderlandy 51,6\%. Najmniejszymi wskaźnikami odznaczają się Węgry 41,0\%, Włochy 41,2\%, Grecja 43,0\% i Belgia 43\%, Hiszpania 43,0\% oraz Polska 44,8\%.

Inny aspekt aktywności zawodowej ludności przedstawia współczynnik aktywności zawodowej, który waha się w Europie od 48,1\% do 67,4\%, przy 56,8\% w Polsce. Obrazuje on stopień wykorzystania zasobów pracy. Najwyższymi współczynnikami charakteryzują się Szwajcaria 67,4\%, Norwegia 65,6\%, Dania 65,5\%. Najniższymi współczynnikami odznaczają się Włochy $48,1 \%$, Grecja 50,0\%, Hiszpania 50,5\%. Polska znajduje się w grupie państw o umiarkowanych wielkościach współczynnika aktywności zawodowej. (Mały rocznik statystyczny Polski 2002)

Poziom wykształcenia poszukujących pracy ma wpływ na możliwości znalezienia zatrudnienia na rynku pracy (tab. 4). W Polsce w maju 2002 roku wśród osób z wyższym wykształceniem współczynnik aktywności zawodowej wynosił 81,4\%, a wskaźnik zatrudnienia $75,8 \%$. Natomiast najtrudniej $\mathrm{z}$ pracą było wśród osób z zasadniczym zawodowym wykształceniem, gdzie współczynnik aktywności zawodowej wynosił 70,9\%, a wskaźnik zatrudnienia - 52,3\%. (Rocznik statystyczny GUS,2003).

Tab. 4. Aktywność ekonomiczna ludności w wieku 15 lat i więcej wg poziomu wykształcenia na podstawie NSP w 2002 roku.

\begin{tabular}{|l|r|r|r|r|r|r|r|}
\hline $\begin{array}{l}\text { Wyszczegól- } \\
\text { nienie }\end{array}$ & Ludność & $\begin{array}{l}\text { Aktywni } \\
\text { zawod. } \\
\text { ogółem } \\
\text { w tys. }\end{array}$ & $\begin{array}{l}\text { Pracu- } \\
\text { jący }\end{array}$ & $\begin{array}{l}\text { Bezro- } \\
\text { wotni }\end{array}$ & $\begin{array}{l}\text { Wsp. } \\
\text { aktywn. } \\
\text { z tys. } \\
\text { w tys. }\end{array}$ & $\begin{array}{l}\text { Wsk. } \\
\text { zatru- } \\
\text { zanienia } \\
\text { w \% }\end{array}$ & $\begin{array}{l}\text { Stopa } \\
\text { bezro- } \\
\text { bocia } \\
\text { w \% }\end{array}$ \\
\hline Ogółem & $\mathbf{3 1 2 8 8 , 4}$ & $\mathbf{1 6 7 7 6 , 5}$ & $\mathbf{1 3 2 1 8 , 3}$ & $\mathbf{3 5 5 8 , 2}$ & $\mathbf{5 5 , 5}$ & $\mathbf{4 3 , 7}$ & $\mathbf{2 1 , 2}$ \\
\hline Wyższe & 3203,6 & 2562,9 & 2386,4 & 176,5 & 81,4 & 75,8 & 6,9 \\
\hline Policealne & 1023,9 & 754,8 & 640,7 & 114,1 & 75,3 & 64,0 & 15,1 \\
\hline $\begin{array}{l}\text { Średnie zawo- } \\
\text { dowe }\end{array}$ & 6382,5 & 4406,1 & 3574,7 & 831,4 & 70,4 & 57,1 & 18,9 \\
\hline $\begin{array}{l}\text { Średnie ogól- } \\
\text { nokształcące }\end{array}$ & 2802,0 & 1349,0 & 1013,0 & 336,0 & 49,3 & 37,0 & 24,9 \\
\hline $\begin{array}{l}\text { Zasadnicze } \\
\text { zawodowe }\end{array}$ & 7539,8 & 5232,8 & 3857,9 & 1374,9 & 70,9 & 52,3 & 26,3 \\
\hline $\begin{array}{l}\text { Podstawowe i } \\
\text { niepełne podst. }\end{array}$ & 9686,0 & 2455,8 & 1733,6 & 722,2 & 25,6 & 18,1 & 29,4 \\
\hline
\end{tabular}

Źródło: Rocznik statystyczny GUS, 2003, s. 141

W ostatnich latach w Polsce nastąpił wzrost liczby ludności w wieku produkcyjnym, co spowodowało wzrost podaży pracy. Nastąpił bowiem wzrost udziału młodzieży w wieku 18-24 lat w ogólnej liczbie ludności z 10\% w 1995r do 12\% w 2000 r. (Padowicz 2002)

W omawianym okresie transformacji nastąpiła znaczna zmiana form własności przedsiębiorstw. Nastąpił wzrost własności prywatnej. Wynikło to między in. z procesów prywatyzacyjnych, zmian statusu przedsiębiorstw, szybkiego rozwoju prywatnych podmiotów gospodarczych. Spowodowało to obecnie, że znaczna część pracujących jest zatrudniona w sektorze prywatnym (ryc. 4). Zgodnie z Małym rocznikiem statystycznym GUS 2002 oraz 2004 struktura pracujących według sektorów własności (na dzień 31 XII) przedstawia się następująco:

- $\quad$ w 1990 roku sektor publiczny zatrudniał 52,1\% pracujacych, a sektor prywatny $47,9 \%$;

- w 2003 roku sektor publiczny zatrudniał $29,8 \%$ pracujących, a sektor prywatny $70,2 \%$. 
W. Padowicz (2002) uważa, że zmiany te przyczyniły się do wzrostu bezrobocia, bowiem rozwój sektora prywatnego nie wystarczył do skompensowania ubytków miejsc pracy w sektorze publicznym.

Ryc. 4. Pracujący według sektorów własności.

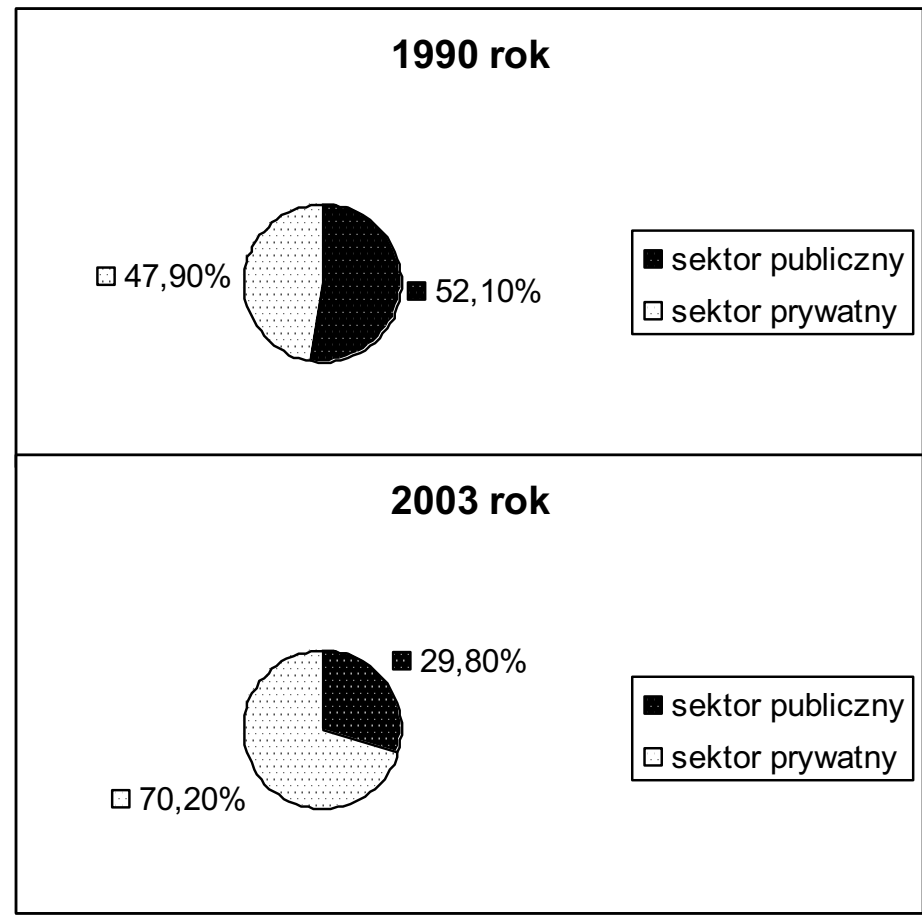

Źródło : Mały rocznik statystyczny GUS 2002, s. 140 oraz 2004

Podsumowując rozważania dotyczące problematyki rynku pracy w edukacji przedsiębiorczości należy zauważyć, że uczeń poszukując pracy po zakończeniu nauki znajdzie się w trudnej sytuacji. Już w czasie trwania nauki powinien zdać sobie sprawę, jak ważne jest zdobywanie wykształcenia. Powinien uświadomić sobie, że wysokie kwalifikacje stworzą mu większe możliwości zatrudnienia na europejskim rynku pracy. Poznanie reguł funkcjonowania rynku pracy, ułatwi mu zrozumienie zachodzących procesów, co pomoże mu podejmować decyzje w czasie poszukiwania pierwszej pracy oraz w okresie późniejszym.

\section{LITERATURA}

Dach Z., 1994, Rynek pracy [w:] Transformacje systemu ekonomicznego w Polsce (red. S. Lis) Wyd. „Secesja”, Kraków, s. $65-70$.

Dowgiałło Z., 1993, Słownik ekonomiczny dla przedsiębiorcy $w$ warunkach rynku, Wydawnictwo Znicz, Szczecin.

Gogolewska J., 1999, Regulowanie rynku pracy [w:] Polityka gospodarcza (red. B. Winiarski) Wydawnictwo Naukowe PWN, Warszawa, s. 466-489.

Grzywacz W., 2002, Podstawy makroekonomii, Wyd. Polskie Towarzystwo Ekonomiczne, Szczecin.

Guzik H.,1999, Polityka zatrudnienia $w$ warunkach rynkowych [w:] Polityka ekonomiczna (red. A. Fajferek) Wyd. Akademii Ekonomicznej, Kraków, s. 219 - 230. 
Kryńska E., 2001, Elastyczność zatrudnienia w Polsce $i$ w Unii Europejskiej, „Gospodarka Narodowa" nr 1-2, s. 74-95.

Mały rocznik statystyczny Polski,2002,2004, GUS, Warszawa.

Padowicz W., 2002, Rosnace bezrobocie i kryzys zatrudnienia w Polsce (przyczyny i uwarunkowania), „Praca i zabezpieczenie społeczne” nr 1, s. 2-11.

Penc J., 1997, Leksykon biznesu, Agencja wydawnicza „Placet”, Warszawa.

Roczniki Statystyczne GUS za lata1994-2003, Warszawa.

Zalega T., 2002, Rynek pracy w epoce cywilizacji informacyjnej, „Nowe Życie Gospodarcze” nr 5 s. $40-42$. 